\title{
HERMENEUTIKA HADIS MUHAMMAD SYAHRUR
}

\author{
Latifah Anwar \\ Universitas Islam Negeri Sunan Ampel Surabaya, Indonesia \\ Email: latifah.anwar@uinsby.ac.id
}

\begin{abstract}
Muhammad Syahrur's point of view about hadith and sunnah was very different from hadith preacher expert. Syahrur declared that hadith was Prophet Muhammad's life as a prophet (messenger) and hadith was the result of his interaction with the certain events in the different situation when he was alive. Muhammad Syahrur positioned hadith and sunnah as the result of history product which happened in Prophet Muhammad's life and did not accommodate law legitimation. Further, he mentioned some rejected hadith practices, although it was identified as hadith shahih, or written in Shahibain. In understanding hadith, Syahrur equalized hermeneutics to ta'wil. He also referred to linguistic method proposed by Abu 'Ali al-Farisi, which was presented by Ibn Jinni and Abd al-Qahir alJurjani, then inserted linguistic hermeneutics elements. Linguistic hermeneutics is the affirmation that every human language does not have synonym element. Then, every word might be disappeared throughout the history development, until create new utterance with the new meaning.
\end{abstract}

Keywords: Hadith; Hermeneutics; Muhammad Syahrur

\begin{abstract}
Abstrak
Pandangan Muhammad Syahrur tentang hadis dan sunnah sangat berbeda dengan ulama hadis. Syahrur menyatakan bahwa hadis adalah kehidupan Nabi Muhammad Saw. sebagai seorang nabi (pembawa berita) dan hadis merupakan hasil interaksi beliau dengan kejadian-kejadian tertentu dalam situasi tertentu pula ketika beliau masih hidup. Muhammad Syahrur memosisikan hadis atau sunnah sebagai hasil dari produk sejarah yang terjadi dalam kehidupan Nabi Saw. dan tidak memuat legitimasi hukum. Bahkan ia memaparkan beberapa bentuk hadis yang ditolak meskipun hadis tersebut dikenal sahih, atau tertera di dalam kitab Shahihain. Dalam memahami hadis, Syahrur menyamakan hermeneutik dengan ta'wil dan ta'wil adalah hermeneutik. Ia juga berpegang kepada metode lingusitik Abu 'Ali al-Farisi, yang direpresentasikan oleh Ibn Jinni dan
\end{abstract}

116 | TAJDID vol. 20, No. 1, Januari - Juni 2021 
'Abd al-Qahir al-Jurjani kemudian menambahnya dengan unsur-unsur hermeneutika lingustik. Hermeneutika linguistik adalah penegasan bahwa setiap bahasa manusia tidak memiliki unsur sinonimitas. Kemudian, setiap kata bisa saja lenyap sesuai dengan perkembangan sejarah, hingga mendatangkan ungkapan baru yang bermakna baru.

Kata Kunci: Hadis; Hermeneutika; Muhammad Syahrur

\section{Pendahuluan}

Definisi sunnah dalam paradigma mayoritas ulama hadis, fikih dan ushul mengindikasikan sinonimitas antara hadis dan sunnah. Berbeda dengan definisi Syahrur, ia mengawali fokus analisisnya pada perdebatan tentang apakah segala yang muncul dari Nabi Muhammad Saw., selain hal-hal yang berkaitan dengan prinsipprinsip agama, merupakan wahyu atau ijtihad individual Nabi Muhammad Saw. ${ }^{1}$

Pada periode pasca Nabi dan sahabat, saat berlangsungnya persemaian tradisi pemikiran Islam klasik, persoalan-persoalan hermeneutis dalam pengertian teoritik sudah mulai muncul dalam tubuh Islam. ${ }^{2}$ Kajian hermeneutika pada awal perkembangannya merupakan cara untuk menginterpretasikan teks keagamaan dengan sebuah interpretasi yang berkembang di Gereja. Pada perkembangan berikutnya ia tumbuh sebagai ilmu dengan ruang lingkup yang lebih luas, tidak hanya terbatas pada teks suci keagamaan. Di antara aliran tersebut yaitu hermeneutika filosofis, hermeneutika romantis, hermeneutika historis, dan lain lain. ${ }^{3}$

${ }^{1}$ M Wahid Syafi, "Sunnah Dalam Pandangan Muhammad Syahrur Dan Fungsinya Dalam Menafsirkan Al-Qur'an: Studi Analisis Tentang Poligami," Jurnal Manthiq 5, no. 2 (April 16, 2020): 106, https://doi.org/10.29300/MTQ.V5I2.4388.

2 Ilyas Supena, Hermeneutika Al-Qur'an Dalam Pandangan Fazlur Rabman (Yogyakarta: Penerbit Ombak, 2014), 40.

${ }^{3}$ Muhammad Yusuf, "BACAAN KONTEMPORER : Hermeneutika AlQur'an Muhammad Syahrur,” Jurnal Diskursus Islam 2, no. 1 (April 22, 2014): 59, https://doi.org/10.24252/JDI.V2I1.6509. 
Syahrur menganggap bahwa standar sebuah metode pemahaman teks keagamaan tergantung pada kontemporelitas dan relevansi metode tersebut dengan karakter teks secara umum dan tidak ditentukan oleh latar ideologis dan geneologis metode tersebut. Dengan berbekal kemampuannya dalam berbagai bahasa dunia seperti bahasa Inggris, Arab, dan Rusia serta penguasaannya dalam bidang ilmu filsafat, Syahrur berusaha mengkaji dan melakukan pembacaan ulang terhadap teks-teks keagamaan. ${ }^{4}$

Terkait dengan hermeneutika filosofis, hermeneutika yang ditawarkan Syahrur juga tidak lepas dari landasan filosofis sebagai hal yang penting untuk dikupas sebelum mengetahui prosedur motodologi hermeneutisnya itu tidak lepas dari pandangan filosofisnya terhadap upaya untuk menginterpretasi yang merupakan konsep dasar hermeneutika syahrur. Ada tiga kata kunci dasar yang menjadi landasan filosofis dalam proyek hermeneutika Syahrur, pertama, kainunah yang merupakan derivasi dari kata kana berarti berada atau kondisi berada (being). Kedua, sairurah merupakan derivasi dari kata saara yang bermakna berjalan atau perjalanan sejarah atau kondisi berproses, dan ketiga, shairurah yang merupakan derivasi dari kata shara yang bermakna kondisi menjadi (becoming). ${ }^{5}$

Muhammad Syahrur telah menghasilkan beberapa karya penting, dan merupakan salah satu pemikir Islam kontemporer yang cukup produktif. Di antara karya-karyanya yaitu tentang pemikirannya dalam al-Qur'an dan hadis. ${ }^{6}$ Sunnah dalam pandangan Syahrur adalah hadis dalam pemahaman ulama hadis.

4 Nur Shofa Ulfiyati, "PEMIKIRAN MUHAMMAD SYAHRUR (Pembacaan Syahrur Terhadap Teks-Teks Keagamaan)," Et-Tijarie: Jurnal Hukum Dan Bisnis Syariah 5, no. 1 (December 4, 2018): 63, https://journal.trunojoyo.ac.id/ettijarie/article/view/4597.

5 Yusuf, "BACAAN KONTEMPORER: Hermeneutika Al-Qur'an Muhammad Syahrur," 59.

6 Muhammad Anshori, "Sunnah Dan Kedudukan Muhammad Dalam Pandangan Muhammad Syaḥrūr," Jurnal Ilmiah Ilmu Ushuluddin 17, no. 2 (April 28, 2019): 101, https://doi.org/10.18592/jiu.v17i2.2239. 
Dengan konsep tersebut, maka tidak akan terjadi kerancauan dalam penggunaan istilah. ${ }^{7}$ Syahrur menganggap sunnab Nabi Saw. tidaklah mutlak dan tidak wajib untuk diterapkan di segala zaman. Karena menurut Syahrur, sunnah tersebut adalah upaya Rasulullah dalam menegakkan syariat Allah agar dapat diterapkan pada zamannya. Sunnah Nabi dianggap sebagai bentuk ijtihad Rasulullah dalam penerapan hukum tanpa keluar dari batas-batas ketentuan Allah dalam al-Qur'an. Dalam hal lain, sabda Rasulullah cukup terikat oleh kondisi lokal dan temporal. ${ }^{8}$

Dalam mengkaji suatu hadis, Syahrur terlebih dahulu melihat konteks sejarah pada zaman Rasulullah dan tidak langsung mengaplikasikannya, kemudian hadis tersebut dikontekstualisasikan pada kondisi sekarang. Perlu digaris bawahi bahwa, untuk mengkaji sebuah hadis, Syahrur juga meperhatikan kondisi ekonomi, politik, konteks sosio-kultural dan berbagai problematika yang ada di masyrakat. Sebagai seorang pemikir kontemporer, pemikiran-pemikiran Muhammad Syahrur dilandaskan dengan fenomena-fenomena yang ada di sekitarnya. Dalam beberapa karya tulisnya, Syahrur juga mengkritik pemahaman ulama-ulama klasik yang diadopsi oleh beberapa pemikir modern kontemporer. ${ }^{9}$

Al-Qur'an menjelaskan bahwa Allah mewajibkan para sahabat untuk taat kepada Nabi Saw. di masa hidupnya. Begitu pula sahabat dan umat Islam sesudah sahabat juga diwajibkan mengikuti sunnab Rasulullah setelah beliau wafat. Karena ayat tentang kewajiban taat kepada Nabi Saw. berlaku secara umum dan tidak terbatas ketika Rasulullah masih hidup. ${ }^{10}$ Sunnah Nabawiyah merupakan wahyu dari Allah kepada Rasulullah Saw. yang menjadi

${ }^{7}$ Anshori, 101.

8 Abdul Fatah, "KONSEP SUNNAH PERSPEKTIF MUHAMMAD SYAHRUR," Diroyah : Jurnal Studi Ilmu Hadis 4, no. 1 (September 30, 2019): 31, https://doi.org/10.15575/DIROYAH.V4I1.6012.

9 Anshori, "Sunnah Dan Kedudukan Muhammad Dalam Pandangan Muhammad Syahrūr,” 103.

10 Mushthafa Al-Siba'i, Al-Sunnah Wa Makanatuha Fi Al-Tasyri' Al-Islami (Riyadh: Dar al-Waraq, n.d.), 72. 
dasar agama dan merupakan pondasi dalam membangun agama yang hak. Umat Islam wajib mengikuti sunnah dan tidak boleh menentangnya. Hal tersebut sudah disepakati oleh umat Islam. ${ }^{11}$

Berdasarkan penelusuran penulis, pemahaman Syahrur terhadap hadis tampak berbeda dengan pemahaman mayoritas ulama hadis. Syahrur menganggap hadis maupun sunnab bukanlah wahyu dari Allah Swt. dan tidak termasuk "al-wabyu al-tsani". Syahrur juga menganggap hadis atau sunnah merupakan produk sejarah dan tidak memuat sumber hukum Islam. Karena menurut Syahrur, tidak ada perintah dari Nabi untuk menulis hadis. Menurut penulis, pendapat Syahrur tersebut tidaklah benar, karena dalam hadis dijelaskan bahwa ada seorang sahabat yang berhenti dari kebiasaannya menulis hadis, kemudian Rasulullah Saw. memerintahkannya kembali untuk menulis hadis. Rasulullah juga menegaskan bahwa sabdanya adalah sesuatu yang hak. Selain itu, terdapat ayat-ayat al-Qur'an yang memerintahkan supaya mentaati Rasulullah termasuk apa yang disampaikannya, seperti firman Allah dalam QS. Al-Hasyr [59]: 7 dan QS. Al-Nisa' [4]: 59.

Syahrur memahami hermeneutik sama dengan ta'wil, bahkan dia mengakui bahwa pembacaan ulang terhadap hadis atau sunnah Nabi adalah hasil dari ta'wil. Tetapi, ta'wil yang dimaksud di sini adalah hermeneutik. Dalam hal ini, Syahrur berpegang kepada metode lingusitik Abu 'Ali al-Farisi, yang direpresentasikan oleh Ibn Jinni dan 'Abd al-Qahir al-Jurjani. Kemudian, dia menambahnya dengan unsur-unsur hermeneutika lingustik.

Penelitian dalam karya ilmiah ini merupakan penelitian kepustakaan (library research) yang bahan penelitiannya bersumber dari literatur tertulis. Obyek penelitian yang dipilih oleh peneliti yaitu mengenai hermeneutika hadis Muhammad Syahrur. Peneliti berusaha mengidentifikasi permasalahan yang diteliti melalui data

${ }^{11}$ Muhammad Abu Zahwu, Al-Hadits Wa Al-Mubadditsun Aw Inayah AlUmmah Al-Islamiyah Bi Al-Sunnab Al-Nabawiyah (Riyadh: al-Mamlakah al'Arabiyah al-Su'udiyah, 1984), 20. 
primer dan data sekunder yang berupa buku, artikel ilmiah, kitab, dan literatur tertulis lainnya yang mempunyai relevansi dengan penelitian ini.

Dalam karya ilmiah ini, peneliti menggunakan metode analisis isi (cotent analysis). Metode ini digunakan sebagai upaya untuk mengungkap berbagai informasi di balik data yang disajikan dalam suatu media atau teks. Sedangkan, pendekatan yang digunakan dalam penelitian ini adalah pendekatan deskiptif. Dalam proses analisis data, penggunaan pendekatan deskriptif cukup efektif untuk diterapkan kerena termasuk penelitian kepustakaan yang terdiri dari literatur tertulis.

\section{Hadis dan Sunnah dalam Perspektif Muhammad Syahrur}

Menurut ulama hadis, sunnah adalah sinonim dari hadis. Namun dalam pengertiannya, sunnab adalah seluruh jejak hidup Rasulullah Saw. sejak beliau belum diutus menjadi Nabi dan sesudahnya. Sedangkan pengertian hadis yaitu sesuatu yang diriwayatkan dari Nabi Saw. sesudah diangkat sebagai Rasul, yang berupa perkataan, perbuatan dan ketetapan Rasulullah. Jadi, pengertian sunnab lebih umum daripada pengertian hadis. ${ }^{12}$

Pendapat ulama hadis di atas berbeda dengan pemahaman Syahrur, yang menganggap bahwa hadis adalah kehidupan Nabi Saw. sebagai seorang utusan Allah. Hadis dianggap sebagai hasil interaksi Nabi dengan peristiwa-peristiwa tertentu dan dalam keadaan tertentu pula pada saat Nabi masih hidup. Syahrur menganggap hadis tidak termasuk wahyu dari Allah Swt., karena menurutnya, Rasulullah beserta para sahabat tidak menganggap hadis sebagai bagian dari wahyu. Menurut Syahrur, Rasulullah dan

12 Muhammad 'Ajjaj Al-Khathib, Ushul Al-Hadits: Ulumub Wa Mushthalabuh (Beirut: Dar al-Fikr, 1971), 27. 
para sahabat juga tidak menyuruh untuk menghimpun dan mencatat Hadis. $^{13}$

Menurut Syahrur, sunnah secara etimologis berasal dari kata sanna yang artinya sesuatu yang mudah atau mengalir dengan lancar. Pemahaman tersebut merujuk pada kebiasaan orang Arab ketika mengatakan maa' masnun yang diartikan sebagai air yang mengalir lancar dengan mudah. Pengertian dari segi etimologis ini dapat dipahami bahwa yang dimaksud sunnah yaitu suatu tindakan yang mudah dan lancar.

Pengertian sunnah dari segi terminologis, Syahrur membaginya menjadi tiga kriteria pokok, yaitu: a) Sunnah dianggap sebagai hasil ijtihad Nabi dalam menetapkan hukum tanpa melanggar ketetapan Allah di dalam al-Qur'an dan terikat oleh sifat lokal temporal. b) Sunnah bukanlah suatu yang mutlak dan tidak wajib diamalkan di semua zaman. c) Sunnah adalah ijtihad Rasulullah dalam menetapkan syariat Allah supaya dapat diterapkan di zamannya. ${ }^{14}$

Muhammad Syahrur membedakan antara istilah sunnah dan hadis. Sunnab Nabi Muhammad Saw. dalam pandangannya ialah metode interaksi Nabi Muhammad Saw. dengan al-Kitab sesuai dengan kondisi objektif yang melatarbelakangi kehidupannya. Posisi Nabi Muhammad Saw. dalam konteks ini adalah sebagai teladan bagi umat Islam, termasuk bagaimana beliau menyontohkan berbagai batasan hukum Allah (budud), akhlak, dan segala sesuatu yang termasuk ke dalam wilayah ketaatan tersambung (wa ati"u Allah wa al-Rasul). Dengan kata lain, Syahrur mendefinisikan sunnah Nabi sebagai metode yang berada dalam pergerakan di antara batas-batas hukum Allah (budud) atau berhenti

13 Ardiansyah Ardiansyah, "KONSEP SUNNAH DALAM PERSPEKTIF MUHAMMAD SYAHRUR Suatu Pembacaan Baru Dalam Kritik Hadis," MIQOT: Jurnal Ilmu-Ilmu Keislaman 33, no. 1 (June 2, 2009): 10, https://doi.org/10.30821/MIQOT.V33I1.160.

14 Qaem Aulassyahied, "Studi Kritis Konsep Sunnah Muhammad Syahrur," KALIMAH 13, no. 1 (March 31, 2015): 128-29, https://doi.org/10.21111/klm.v13i1.282. 
pada batas-batas hukum tersebut, atau mengkreasi batas-batas lokal-temporal dalam persoalan yang tidak disinggung dalam alKitab. ${ }^{15}$

Apabila definisi hadis dihubungkan dengan definisi sunnah, maka perbedaan utama di antara keduanya adalah bahwa sunnah Nabi adalah metode interaksi Nabi dengan al-Kitab, sedangkan hadis Nabi merupakan hasil dari interaksi Nabi dengan realitas objektif tertentu. ${ }^{16}$

Syahrur masih menghargai sunnah Nabi sebagai warisan tradisi Islam yang semata-mata menjadi pertimbangan bagi seseorang untuk menetapkan hukum, tetapi tidak menjadikannya sebagai dasar hukum. ${ }^{17}$ Selain itu, Syahrur juga menyatakan bahwa Rasulullah Saw. tidak memiliki wewenang dalam menentukan halal dan haram. Syahrur menilai bahwa sunnah merupakan praktik Rasulullah dan tidak memiliki legitimasi hukum. ${ }^{18}$

Menurut Syahrur, bahwa sejak awal para sahabat tidak memandang hadis sebagai wahyu yang berlaku abadi sebagaimana al-Tanæil (al-Qur'an). Sehingga sampai pada kesimpulan bahwa hadis Nabi Saw. tidaklah seperti apa yang didefinisikan oleh ulamaulama terdahulu yang identik dengan hadis. ${ }^{19}$

Syahrur menganggap bahwa sunnah merupakan ijtihad Nabi dalam mengubah Islam yang mutlak menjadi Islam yang nisbi yang ditujukan untuk masyarakat Arab abad ke-7, dan bukan ditujukan untuk masyarakat seluruh dunia pada semua masa. Oleh karena itu,

${ }^{15}$ Nurul Hakim and Tantin Puspita Rini, "Sunnah Perspektif Muhammad Syahrur," Al-Adabiya: Jurnal Kebudayaan Dan Keagamaan 15, no. 01 (June 5, 2020): 11-12, https://doi.org/10.37680/adabiya.v15i01.264.

${ }^{16}$ Hakim and Rini, 14.

17 M Najmil Husna, "Kritik Matan Hadis Muhammad Syahrūr," Jurnal Ilmu Pendidikan 3 , no. 2 (2016): 116 , https://journal.iainlangsa.ac.id/index.php/ikhtibar/article/view/60.

18 Najmil Husna, 117.

19 Wahid Syafi, "Sunnah Dalam Pandangan Muhammad Syahrur Dan Fungsinya Dalam Menafsirkan Al-Qur'an: Studi Analisis Tentang Poligami," 106. 
definisi sunnah yang diajukan oleh para ahli Ushul Fiqih, di mana sunnah didefinisikan sebagai perkataan Nabi, perbuatan, dan ketetapan yang dikutip dari Nabi, atau juga definisi sunnab yang diajukan oleh para ahli hadis di mana sunnah adalah perkataan Nabi, perbuatan, ketetapan, karakter fisik, etika atau sejarah (baik sebelum ataupun sesudah kenabian) yang diriwayatkan oleh nabi, dalam pandangan Syahrur merupakan definisi yang salah. Karena definisi sunnab semacam ini tidak berangkat dari karakteristik risalah Nabi Muhammad Saw., yaitu shalib li kulli zaman wa makan. Syahrur lebih suka memahami sunnah sebagai kreativitas mujtahid pertama (Nabi Muhammad Saw.) dalam mengaplikasikan Islam untuk zamannya, bukan untuk semua zaman. ${ }^{20}$

Kemudian Syahrur mengklasifikasikan sunnab kepada sunnah alnubuwwah dan sunnah al-risalab. ${ }^{21}$ Menurut Syahrur, sunnab sunnab alnubuwwah yaitu sunnah yang berkaitan dengan pewartaan hal-hal gaib, seperti kisah-kisah israiliyyat, dan juga sunnah yang berisi pengagungan terhadap Rasulullah, atau khabar yang khusus kepada Nabi semata. ${ }^{22}$

Syahrur lalu mengelompokkan sunnah al-nubumwah ini, ke dalam dua kategori: ${ }^{23}$

1. Hadis-hadis tentang hal-hal gaib. Ini harus sesuai dengan realita, dan akal. Jika tidak, maka dapat diabaikan.

2. Hadis-hadis penafsiran, atau penjelasan Nabi terhadap Kitabullah, seperti turunnya al-Qur'an, lailah al-qadr dan sebagainya, harus sejalan dengan al-Qur'an sendiri. Apabila tidak, maka diabaikan.

Sedangkan sunnah al-risalah, yaitu sunnah yang berhubungan dengan hukum-hukum seperti syariat tentang hukum ibadah,

${ }^{20}$ Hakim and Rini, "Sunnah Perspektif Muhammad Syahrur," 14.

21 Ardiansyah, "KONSEP SUNNAH DALAM PERSPEKTIF MUHAMMAD SYAHRUR Suatu Pembacaan Baru Dalam Kritik Hadis,” 11.

${ }^{22}$ Najmil Husna, "Kritik Matan Hadis Muhammad Syahrūr," 120.

${ }^{23}$ Najmil Husna, 120. 
muamalah, dan akhlak. Sunnah tersebut harus ditaati terutama yang berhubungan dengan hukum. Sunnah al-risalah terbagi menjadi dua macam, yaitu: a) Sunnah al-risalah yang berkaitan dengan akhlak dan ibadah. Sunnah tersebut sebagai penjelasan kandungan al-Qur'an dan tidak memuat hukum baru. Sunnah seperti ini harus ditaati ketika Nabi hidup dan sesudah wafatnya beliau. b) Sunnah al-risalah yang hanya ditaati dikala Nabi Saw. masih hidup, sunnab ini berhubungan dengan aktivitas sehari-hari Rasulullah seperti cara berpakaian, minum, makan, dan berperang. Sunnah tersebut dipahami berdasarkan konteks kekinian dan ditaati secara kontektual bukan tekstual. Syahrur memahami kedudukan Rasulullah bukan sebagai pembuat hukum baru yang tidak tertera dalam al-Qur'an dan posisinya sebatas mubayyin. ${ }^{24}$

Muhammad Syahrur tidak membenarkan adanya "al-wahyu altsani" terhadap hadis ataupun sunnah Rasulullah. Ia beranggapan bahwa sunnab atau hadis tidak termasuk wahyu dari Allah Swt. Pemahaman Syahrur tersebut berangkat dari penafsirannya terhadap QS. Al-Najm [53]: $3-4 .^{25}$

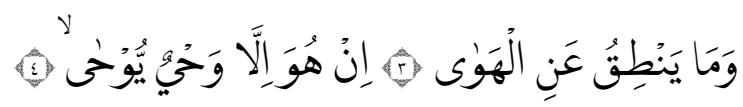

"Dan tidak pula berucap (tentang al-Qur'an dan penjelasannya) berdasarkan hawa nafsu(-nya). Ia (al-Qur'an itu) tidak lain, kecuali wahyu yang disampaikan (kepadanya)."26

Dalam pemahaman Syahrur, maksud rujukan dhamir (kata ganti) هُ dalam QS. Al-Najm [53]: 4 tersebut merujuk terhadap al-Qur'an

24 Ardiansyah, "KONSEP SUNNAH DALAM PERSPEKTIF MUHAMMAD SYAHRUR Suatu Pembacaan Baru Dalam Kritik Hadis," 1112.

25 Ardiansyah, 13.

${ }^{26}$ QS. Al-Najm [53]: 3-4.

TAJDID Vol. 20, No. 1, Januari - Juni 2021 | 125 
dan bukan merujuk terhadap Rasulullah. Dhamir sُ tersebut tidak berhubungan dengan dhamir yang ada pada kalimat يَنْفِ (yanthiqu). ${ }^{27}$

Syahrur melihat bahwa yang dimaksud dhamir is dalam ayat tersebut adalah ayat-ayat al-Qur'an yang diucapkan oleh Rasulullah. Sehingga substansi ucapan Rasulullah dalam ayat tersebut tidak bermakna sabda Rasulullah secara umum, tetapi yang dimaksud adalah al-Qur'an yang diwahyukan. Karena ayat tersebut diturunkan di Mekkah pada saat orang Arab meragukan apa yang diwahyukan kepada Rasulullah, bukan terhadap pribadi Rasulullah. Syahrur menambahkan, jika yang ditujukan oleh ayat tersebut adalah sunnah Rasulullah, maka hal tersebut tidaklah sesuai, karena Raulullah pernah ditegur dengan ayat al-Qur'an. Menurutnya, tidak mungkin suatu wahyu (sunnab Nabi) juga ditegur oleh wahyu (al-Qur'an). ${ }^{28}$

Terdapat dua argumen penting yang mendasari penafsiran ini, yaitu: ${ }^{29}$

1. Perkataan dan perbuatan Rasulullah terlepas dari hawa nafsu dan tidak pula dipengaruhi dengan perasaan jiwa. Tetapi, setiap sabda Rasulullah tidak bisa dianggap sebagai wahyu.

2. Ayat tersebut diturunkan di Makkah, ketika bangsa Arab tidak meyakini otentisitas wahyu yang disampaikan oleh Rasulullah. Menurut Syahrur, maksud ayat tersebut adalah esensi al-Qur'an sebagai wahyu yang diturunkan kepada Rasulullah bukan terhadap sisi pribadi Rasulullah.

Muhammad Syahrur memosisikan hadis atau sunnah sebagai hasil produk sejarah dan merupakan hasil itihad Nabi dalam kehidupannya, dan hal tersebut bisa saja benar atau salah. Kesalahan yang pernah dialami Rasulullah yaitu seperti berpalingnya beliau dari hadapan Ummu Maktum, dan kemudian

27 Ardiansyah, "KONSEP SUNNAH DALAM PERSPEKTIF MUHAMMAD SYAHRUR Suatu Pembacaan Baru Dalam Kritik Hadis," 13.

28 Aulassyahied, "Studi Kritis Konsep Sunnah Muhammad Syahrur," 130.

29 Ardiansyah, "KONSEP SUNNAH DALAM PERSPEKTIF MUHAMMAD SYAHRUR Suatu Pembacaan Baru Dalam Kritik Hadis,” 14. 
turun QS. 'Abasa [80]: 1-3 sebagai teguran. Hal ini menunjukkan bahwa kesalahan tersebut merupakan hasil ijtihad Rasulullah dan tidak termasuk wahyu. Seandainya termasuk wahyu, maka tidak mungkin Allah menegur Rasulullah. ${ }^{30}$

Dalam pandangan Syahrur, Muhammad hanya sebagai mujtahid ketika menempati posisi sebagai Nabi, sehingga ada kemungkinan Nabi keliru ketika melakukan suatu hal. Menurutnya, Nabi Muhammad terpelihara dari kesalahan atau ma'shum ketika dalam posisinya sebagai Rasul. ${ }^{31}$

Syahrur juga menganggap bahwa para imam fikih sengaja melakukan pengultusan sunnah supaya setiap fatwa dari mazhab mereka memiliki legitimasi hukum dan menjadikan sunnah sebagai sumber hukum. ${ }^{32}$

Nampaknya dalam hal ini Syahrur kurang teliti, karena dalam hadis dijelaskan bahwa ada seorang sahabat yang berhenti dari kebiasaannya menulis hadis, kemudian Rasulullah memerintahkannya kembali untuk menulis. Adapun hadisnya sebagai berikut:

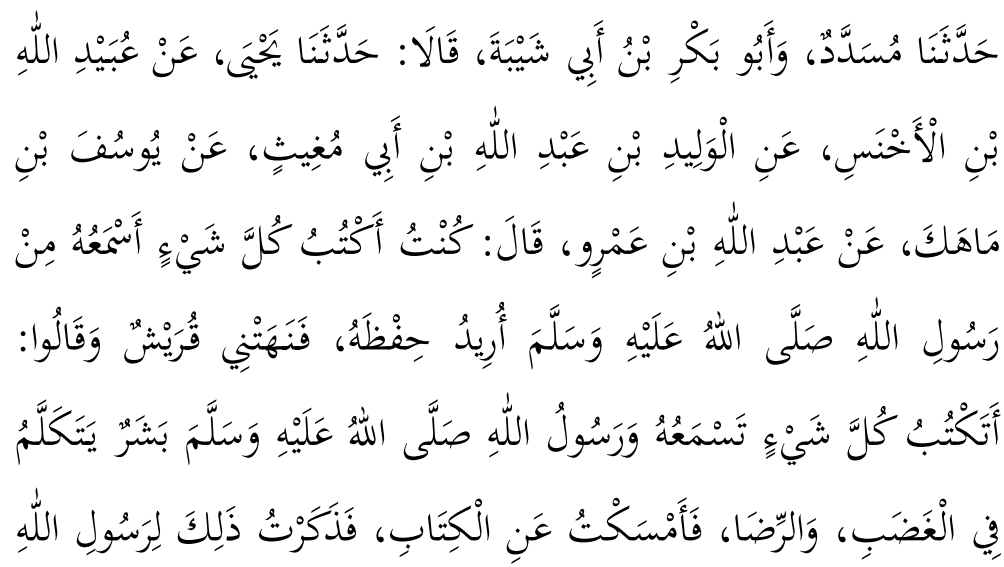

\footnotetext{
30 Ardiansyah, 14.

${ }^{31}$ Aulassyahied, "Studi Kritis Konsep Sunnah Muhammad Syahrur," 130.

32 Aulassyahied, 131.
} 


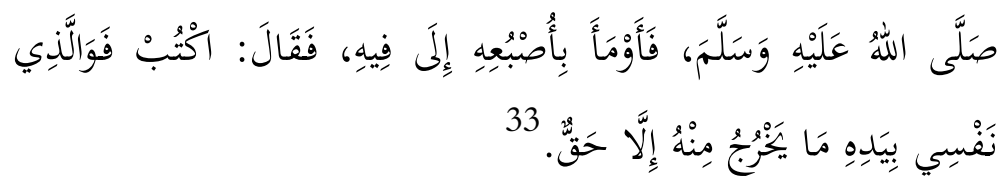

"Telah menceritakan kepadaku Musaddad dan Abu Bakr ibn Abi Syaibah, keduanya berkata: telah menceritakan kepadaku Yahya, dari 'Ubaydillah ibn al-Akhnas, dari al-Walid ibn 'Abdillah ibn Abi Mughits, dari Yusuf ibn Mahak, dari 'Abdillah ibn 'Amr, ia berkata: "Aku menulis setiap sesuatu yang aku dengar dari Rasulullah Saw. untuk dihafal. Lalu ada orang-orang Quraisy melarangku, mereka berkata: apakah kamu menulis setiap sesuatu yang kamu dengar dari Rasulullah sedangkan ia adalah manusa biasa yang juga akan berbicara ketika marah dan ketika ia ridha, kemudian aku berhenti menulis hadis. Lalu aku menceritakan hal itu kepada Rasulullah Saw., kemudian Rasulullah Saw. mengarahkan jarinya ke mulutnya lalu bersabda: "Tulislah demi Dzat yang jiwaku dalam kekuasaan-Nya, tidaklah keluar darinya (mulutku) kecuali sesuatu yang hak."

Menurut Syahrur, sunnah merupakan ijtihad temporal Nabi dan Syahrur menganggap sunnab bukan sebagai sumber hukum dan bukan wahyu dari Allah. Syahrur mengungkap beberapa alasan penting yang mengacu pada beberapa hal, di antaranya, yaitu: a) Praktik dari sahabat Nabi Saw. yang tidak menulis hadis; b) Rasulullah tidak mempunyai hak dalam menentukan hukum. ${ }^{34}$

Pendapat Syahrur yang menganggap sunnah bukan wahyu dan bukan sumber hukum Islam menurut penulis tentu sangat keliru, karena Rasulullah menegaskan bahwa sabdanya adalah sesuatu yang hak, dan dalam al-Qur'an banyak sekali ayat yang memerintahkan supaya mentaati Rasulullah termasuk apa yang

33 Abu Dawud Sulayman ibn al-Asy'ats Al-Sijistani, Sunan Abu Dawnd (Riyadh: Bayt al-Afkar al-Dawliyyah, n.d.), 403.

34 Aulassyahied, "Studi Kritis Konsep Sunnah Muhammad Syahrur," 140. 
disampaikannya, seperti yang dijelaskan dalam ayat-ayat dalam al-Qur'an:

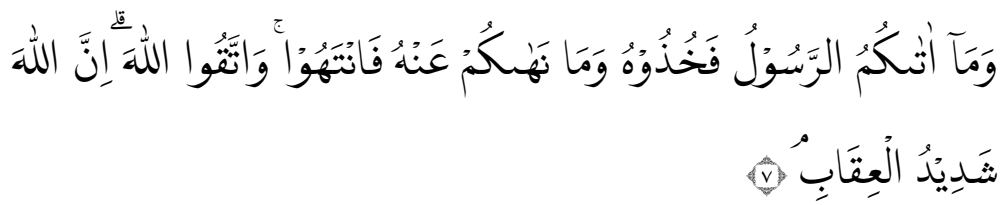

"Apa yang diberikan Rasul kepadamu terimalah. Apa yang dilarangnya bagimu tinggalkanlah. Bertakwalah kepada Allah. Sesungguhnya Allah sangat keras hukuman-Nya.",35
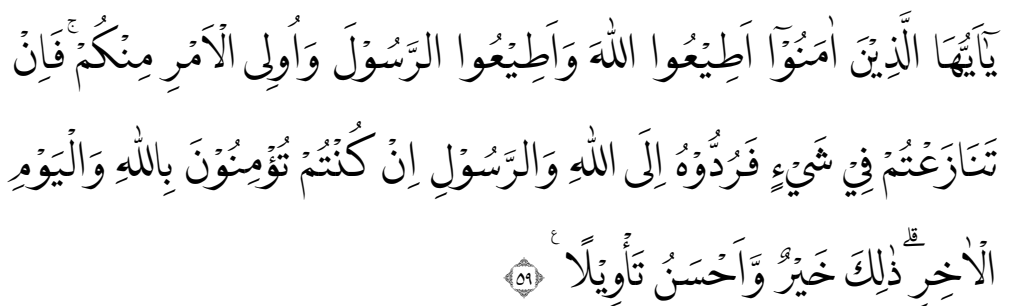

"Wahai orang-orang yang beriman, taatilah Allah dan taatilah Rasul (Nabi Muhammad) serta ululamri (pemegang kekuasaan) di antara kamu. Jika kamu berbeda pendapat tentang sesuatu, kembalikanlah kepada Allah (al-Qur'an) dan Rasul (sunnabnya) jika kamu beriman kepada Allah dan hari Akhir. Yang demikian itu lebih baik (bagimu) dan lebih bagus akibatnya (di dunia dan di akhirat).",36

Allah telah mewajibkan pada kita untuk taat kepada Rasulullah Saw. Siapapun yang menerima ketetapan dari Rasulullah maka ia sudah menerima kewajiban dari Allah. ${ }^{37}$ Setiap sesuatu dari hadis adalah penjelas bagi syariat Allah yang telah tertulis dalam al-Qur'an, karena Rasulullah Saw. adalah

35 QS. Al-Hasyr [59]: 7.

${ }^{36}$ QS. Al-Nisa' [4]: 59.

37 Muhammad ibn Idris Al-Syafici, Al-Risalah (Beirut: Dar al-Kutub al'Ilmiyyah, n.d.), 22. 
mubayyin dari Tuhannya, dan yang diperintahkan untuk menegakkan agama-Nya. ${ }^{38}$

\section{Penolakan Muhammad Syahrur terhadap Hadis}

Setelah mengacak ulang defenisi sunnah, dan membelahnya menjadi dua bagian, lalu Syahrur memaparkan beberapa bentuk hadis Nabi yang ditolak, dengan berbagai alasan, meskipun hadis tersebut dikenal sahih, atau tertera di dalam kitab Shahihain, antara lain: ${ }^{39}$

1. Menolak semua hadis yang menyangkut hal-hal gaib, mulai dari riwayat-riwayat tentang kematian, hari kiamat, hingga surga dan neraka. Menurutnya, yang mengetahui hal-hal tersebut hanyalah Allah. Bahkan Nabi sekalipun, tidak mengetahui hal yang gaib. Kalaupun dia mengetahuinya, maka hal itu tidak disampaikan kepada umat, sebab kalau disampaikan, maka tidak akan menjadi gaib lagi.

2. Menolak semua hadis tentang kegaiban Zat Allah, 'arsy, kursy, lawh mahfurh, karena hal tersebut hanya bisa diketahui dari al-Qur'an.

3. Menolak semua hadis tentang penciptaan Adam, alam semesta, dan mukjizat para Rasul. Karena menurutnya mirip dengan kisah-kisah Isra'iliyyat dan Nasraniyyat, seperti yang tertera di dalam perjanjian baru dan perjanjian lama.

4. Menolak semua hadis yang dianggap sebagai naskh terhadap al-Qur'an.

5. Menolak semua hadis tentang asbab an-nuzul ayat al-Qur'an, apalagi yang menerangkan sesuatu yang mubham dari ayat, karena riwayat hadis-hadis yang demikian mirip dengan cerita Isra'iliyyat dan Nasraniyyat.

\footnotetext{
38 Al-Syafici, 33.

${ }^{39}$ Najmil Husna, "Kritik Matan Hadis Muhammad Syahrūr," 120-22.
}

130| TAJDID vol. 20, No. 1, Januari - Juni 2021 
6. Menolak semua hadis, yang teksnya bertentangan dengan rasa kemanusiaan, keadilan, dan tanggung jawab individu. Karena menurut Syahrur, hadis-hadis tersebut tidak sejalan dengan prinsip-prinsip al-Qur'an.

7. Menolak semua hadis yang kelihatan merendahkan wanita, baik dari segi penciptaannya, hak-haknya, pembagian warisan kepadanya, karena hal ini semua harus dirujuk kembali ke alQur'an.

8. Menolak semua hadis yang menceritakan mukjizat-mukjizat Nabi, karena hadis yang seperti ini, bertentangan dengan kaidah pokok Islam, yaitu hanya al-Qur'an yang menjadi mukjizat, tidak ada yang lain.

9. Menolak semua hadis yang menetapkan keistimewaan khusus, baik bagi individu seseorang, daerah, suku, atau yang sejenisnya, karena hal ini bertentangan dengan kaidah pokok Islam, yaitu hanya ketakwaan dan amal perbuatan yang mendatangkan keistimewaan. Tidak ada yang lain.

10. Menolak semua hadis yang bertentangan dengan kebebasan dan kemerdekaan seseorang dalam memilih agama. Sekalipun ada hadis yang sahih tentang hal tersebut, maka menurutnya, telah berakhir pemberlakuannya. Ia hanya berlaku di masa Nabi, tidak berlaku lagi di masa sekarang.

11. Menolak semua hadis yang bertentangan dengan al-Qur'an, tanpa kompromi. Seperti hadis tentang haramnya menikahi wanita dan bibinya.

12. Menolak semua hadis yang berkaitan dengan petunjukpetunjuk harian dalam menjalani kehidupan, seperti hadishadis makanan, minuman, pakaian, kendaraan dan sebagainya, karena hal ini semua adalah kebiasaan Arab, yang menjadi tradisi Nabi. Bagi orang sekarang, diberikan kebebasan untuk menentukan sunnahnya.

13. Menolak semua hadis yang mengandung ancaman, atau 
hukuman yang berat bagi kesalahan yang kecil, atau hadis yang mengandung gambaran pahala yang besar, bagi perbuatan amal yang tertentu, seperti pahala zikir-zikir, wirid-wirid, dan pahala salat-salat tertentu. Hal ini semua menunjukkan ketidakadilan, dan bertentangan dengan prinsip pokok ajaran Islam.

Dilihat dari berbagai karakter hadis yang ditolak ini, tampak bahwa hampir semua jenis hadis, yang sering dijadikan landasan para ulama dalam ber-istidlal, dibatalkan dan dicampakkan begitu saja. Syahrur kelihatannya, ingin mengarahkan pemahaman kepada kebebasan berfikir dan ber-istidlal, tanpa terikat dengan sunnah Nabi. ${ }^{40}$

Para ulama sepakat bahwa hadis sahih dapat dijadikah bujjah untuk menetapkan syariat Islam baik hadis itu ahad terlebih yang mutawatir. Namun, mereka berbeda pendapat dalam hal hadis sahih yang abad dijadikan bujjah di bidang akidah. Perbedaan terjadi karena perbedaan penilaian mereka tentang hadis sahih yang abad itu berstatus atau berfaedah qathi (pasti) sebagaimana hadis mutawatir, atau berfaedah z̧hanni (samar). Ulama yang memahami bahwa hadis sahih yang abad sama dengan hadis sahih yang mutawatir, yakni berstatus qath ' , berpendapat bahwa hadis abad dapat dijadikan bujjah di bidang akidah. Tetapi bagi ulama yang menilainya berstatus zhanni, menyatakan bahwa hadis sahih yang ahad tidak dapat dijadikan hujjah di bidang akidah. ${ }^{41}$

\section{Hermeneutika Hadis Muhammad Syahrur}

Teks dalam pandangan hermeneutika selalu memiliki dua komponen; struktur gagasan pengarang dan aktualisasi gagasan tersebut ke dalam struktur bahasa. Struktur gagasan dan struktur bahasa inilah yang harus diperhatikan secara bersama-sama dalam memahami sebuah teks. Karena itu, teks harus dipahami dengan

\footnotetext{
${ }^{40}$ Najmil Husna, 123.

${ }^{41}$ Idri, Studi Hadis (Jakarta: Kencana, 2010), 175.
} 
model lingkar hermeneutika antara the world of the text, the world of the author dan the world of the reader secara integral. ${ }^{42}$

Dalam pandangan Syahrur, hermeneutik dipersamakan dengan ta'wil, bahkan dia mengakui bahwa pembacaan ulang terhadap sunnah Nabi adalah hasil dari ta'wil. Tetapi, ta'wil yang dimaksud di sini adalah hermeneutik. ${ }^{43}$

Keyakinan teologi umat Islam tentu saja sangat berbeda dengan keyakinan teologis umat kristen mengenai Bibel. Mereka menyadari bahwa Bibel mempunyai beberapa penulis yang dianggap mendapat inspirasi dari roh kudus seperti Markus, Yohannes, Matius dan sebaginya. Kenyataan ini kemudian mempengaruhi struktur keimanan atau credo umat kristen untuk tidak mengatakan Bibel sebagai kalam Tuhan (The Word of God). Berdasarkan keyakinan ini, para teolog kristen memerlukan hermeneutika sebagaimana diakui Schleiermacher untuk memahami teks sebaik atau lebih baik daripada pengarangnya. ${ }^{44}$

Sebenarnya, hermeneutika adalah alat bagi para cendikiawan Kristen Protestan, sekitar abad 16 M. yang mereka adopsi untuk memahami Bibel. Lalu, objek kajian hermeneutik ini berkembang hingga mencakup bidang-bidang humaniora, seperti sejarah, sosioloi, antropologi, dan estetika. Sedangkan pada masa sekarang, hermeneutik malah masuk ke ranah studi ajaran dasar Islam (alQur'an dan hadis Nabi). Dengan mengikuti perkembangannya, maka Syahrur tidak mau ketinggalan. Dia juga mengadopsi teknik hermeneutik ini dalam memahami hadis, atau malah mengkritiknya. ${ }^{45}$

Penafsiran yang solid adalah penafsiran dalam memahami makna secara benar dan dengan sudut pandang yang netral. Memahami makna suatu teks adalah pemahaman yang sama

${ }^{42}$ Supena, Hermeneutika Al-Qur'an Dalam Pandangan Fąlur Rabman, 18.

${ }^{43}$ Najmil Husna, "Kritik Matan Hadis Muhammad Syahrūr," 130.

${ }^{44}$ Supena, Hermeneutika Al-Qur'an Dalam Pandangan Fazlur Rabman, 39.

45 Najmil Husna, "Kritik Matan Hadis Muhammad Syahrūr," 130. 
dengan apa yang dimaksud oleh pengarang yang sejalan dengan simbol-simbol bahasa yang digunakan secara spesifik sehingga terdapat kesamaan. ${ }^{46}$

Ada tiga prinsip kebahasaan Abu Ali al-Farisi yang dipegang oleh Syahrur. Selain menganggap ketiadaan sinonimitas dalam bahasa, Syahrur juga mengadopsi dan memegang tiga prinsip kebahasaan Abu Ali al-Farisi, yaitu: a) bahasa merupakan sebuah sistem kesepakatan; b) bahasa merupakan fenomena sosial dan konstruksinya berhubungan dengan konteks dimana ia disampaikan; c) ada keterkaitan antara bahasa dan pemikiran. ${ }^{47}$

Syahrur sendiri berpegang kepada metode lingusitik Abu 'Ali al-Farisi, yang direpresentasikan oleh Ibn Jinni dan 'Abd alQahir al-Jurjani. Kemudian, dia menambahnya dengan unsurunsur hermeneutika lingustik. Di antara kesimpulan terpenting hermeneutika linguistik adalah, penegasan bahwa setiap bahasa manusia, tidak terkecuali bahasa Arab, tidak memiliki unsur sinonimitas (kesamaan ungkapan). Kemudian, setiap kata bisa saja lenyap sesuai dengan perkembangan sejarah, hingga mendatangkan ungkapan baru yang bermakna baru. ${ }^{48}$

Dengan berpegang terhadap ketiga prinsip al-Farisi dan terhadap pemikir dua tokoh bahasa Arab lainnya, Syahrur mengkonstruk prinsip metode penafsiran terkait dengan kebahasaan. Pertama, ada keterkaitan antara ucapan, pemikiran, dan fungsi bahasa sebagai alat penyampai gagasan. Kedua, bahasa sebagaimana pemikiran, tidak tumbuh sekaligus dengan sempurna (sinkronik). Awalnya, pemikiran hanya bersifat indrawi dan personifikasi (idrak makhsus wa musyakhkhas) kemudian menjadi bersifat abstrak. Sedang bahasa awalnya hanya untuk mengungkap

46 Pascasarjana IAIN Sunan Ampel Surabaya, Hermeneutika Dan Fenomenologi Dari Teori Ke Praktike (Surabaya: Pascasarjana IAIN Sunan Ampel Surabaya, 2007), 98.

47 Yusuf, "BACAAN KONTEMPORER: Hermeneutika Al-Qur'an Muhammad Syahrur," 62.

48 Najmil Husna, "Kritik Matan Hadis Muhammad Syahrūr," 130. 
hal yang terindra kemudian terabstraksikan dalam tata bahasa (nabw dan sharaf). Ketiga, mengingkari sinonimitas. ${ }^{49}$

Syahrur mengemukakan beberapa prinsip hermeneutik di antaranya, yaitu: a) hanya dengan membaca teks saja pembaca bisa memahami maksud penulis, tanpa harus merujuk kepada penulis teks; b) tidak ada yang berhak menyatakan keabsolutan pemahaman, atas apa yang dia baca; c) ketiadaan seorang Nabi setelah Nabi Muhammad Saw., menunjukkan bahwa pemahaman terhadap teks-teks keagamaan akan selalu relatif; d) fleksibilitas makna dapat diterapkan sesuai kondisi sosial yang berubah; e) Teks-teks keagamaan termasuk al-Qur'an dan sunnah tidak mengalami persamaan makna suatu kata yang absolut. ${ }^{50}$

Posisi Syahrur sejalan dengan pendapat yang menolak sinonimitas karena ia menggabungkan teori sinkronik Ibnu Jinni dan teori diakronik al-Jurjani, karena keduanya saling melengkapi dan terkait dengan sejarah kata-kata. Jika mengakui sinonim berarti ia mengingkari sejarah kata-kata karena setiap kata mempunyai makna sesuai konteks penggunannya yang terus berkembang. ${ }^{51}$

Adapun contoh hadis yang berkaitan dengan pola hermeneutik lingusitik yang digunakan oleh Syahrur adalah sebagai berikut:

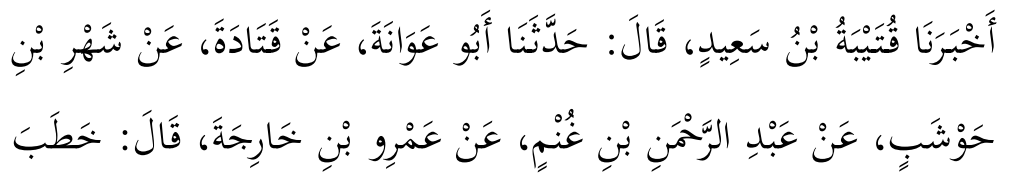

49 Yusuf, "BACAAN KONTEMPORER: Hermeneutika Al-Qur'an Muhammad Syahrur," 62-63.

${ }^{50}$ Najmil Husna, "Kritik Matan Hadis Muhammad Syahrūr," 131.

51 Yusuf, "BACAAN KONTEMPORER: Hermeneutika Al-Qur'an Muhammad Syahrur," 63. 


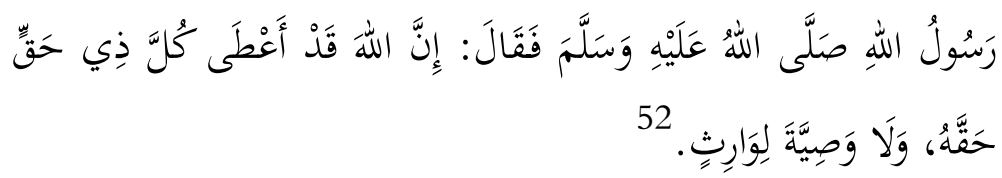

"Qutaibah bin Sa'id mengkhabarkan kepada kami, dia berkata: Abu 'Awanah telah menceritakan kepada kami dari Qatadah dari Syahr bin Hawsyab dari 'Abd al-Rahman bin Ghunm dari 'Amr bin Kharijah, dia berkata: Rasulullah Saw. berkhutbah, kemudian bersabda: "Sesungguhnya Allah telah memberikan kepada tiap-tiap yang berhak terhadap haknya, dan tidak ada wasiat untuk ahli waris."

Syahrur juga berasumsi bahwa tidak ada naskh-mansuk h $^{53}$ dalam syariat. Kemudian ia mulai membongkar hadis tersebut, dengan diawali dari analisis linguistik. Menurutnya, kata berasal dari gang terdiri dari tiga huruf وصى ص و ص. Artinya, sampainya sesuatu pada sesuatu yang lain, seperti perkataan seseorang washshaytu al-syai' berarti saya telah menyampaikan sesuatu kepadanya. ${ }^{54}$

Pemaknaan wasiat ini mengacu pada pemahaman bahwa wasiat tidak tergantung pada tempat dan waktu. Ia bermakna universal, dan harus dilaksanakan saat itu juga, dan juga untuk periode sesudahnya. Karenanya, wasiat memuat makna historisitas yang berlapis-lapis, sejak masa Nabi Nuh hingga akhir zaman. Menurut Syahrur wasiat tidak dapat dikalahkan oleh warisan, karena warisan situasional dan kondisional (al-sayrurab), sedangkan wasiat menembus ruang dan batas waktu (al-kaynunab). Oleh karena itu, Syahrur memungkiri jika hadis tersebut dianggap

52 Abi 'Abd al-Rahman Ahmad bin Syu'ayb bin 'Ali Al-Nasa'i, Sunan AlNasa'i (Riyadh: Bayt al-Afkar al-Dawliyyah, n.d.), 387.

53 Naskh adalah menghapus hukum syara' dengan hukum syara' yang datang lebih akhir . Lihat Sayyid 'Abd al-Majid Al-Ghawri, Mawsu'ah 'Ulum AlHadits Wa Fununuh, vol. 3 (Beirut: Dar Ibn Katsir, 2007), 541.

${ }^{54}$ Najmil Husna, "Kritik Matan Hadis Muhammad Syahrūr," 131-32. 
sebagai nasikh terhadap ayat-ayat tentang wasiat kepada ahli waris. ${ }^{55}$ Berikut bunyi ayat tentang wasiat tersebut:

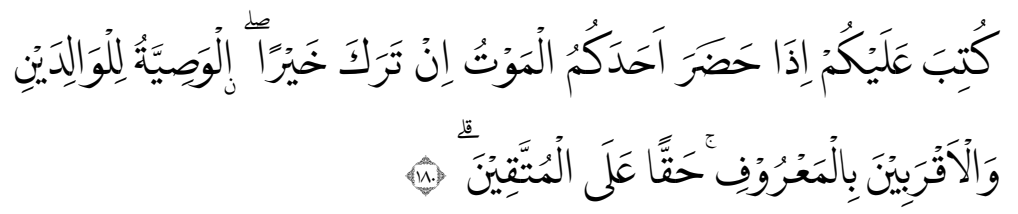

"Diwajibkan kepadamu, apabila seseorang di antara kamu didatangi (tanda-tanda) maut sedang dia meninggalkan kebaikan (harta yang banyak), berwasiat kepada kedua orang tua dan karib kerabat dengan cara yang patut (sebagai) kewajiban bagi orang-orang yang bertakwa." 56

Mengenai boleh tidaknya nasakh al-Qur'an dengan al-sunnah terjadi perbedaan pendapat. Golongan yang tidak membolehkan me-nasakh ayat (al-Qur'an) dengan al-sunnah di antaranya Sufyan al-Tsawri, al-Syafici, Ahmad bin Hanbal, dan sekelompok dari sahabat-sahabat Malik. ${ }^{57}$

Berdasarkan analisa penulis dalam kitab al-Muqaddimah alAsasiyyah fi 'Ulum al-Qur'an, penulis memahami Argumen golongan yang menolak adanya nasakh al-Qur'an dengan al-sunnah yaitu ayat tentang kewajiban berwasiat terhadap ahli waris pada surah alBaqarah ayat 180 di atas di-nasakh dengan surah al-Nisa' ayat 11, sebagai berikut:

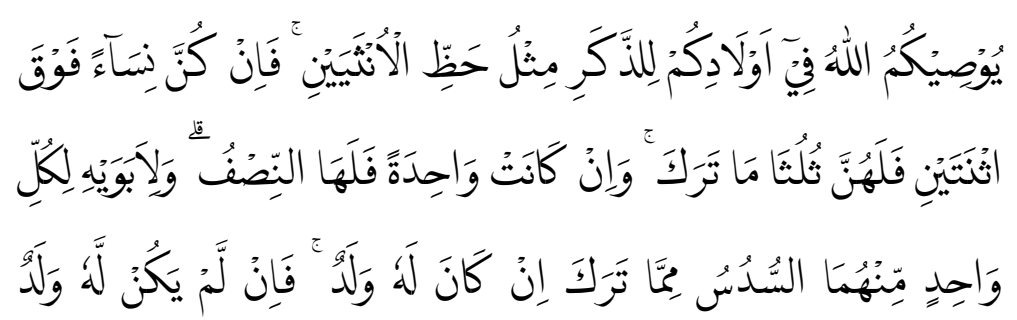

${ }^{55}$ Najmil Husna, 132.

${ }^{56}$ QS. Al-Baqarah [2]: 180.

57 Abdullah bin Yusuf Al-Judai', Al-Muqaddimah Al-Asasiyyah Fi 'Ulum AlQur'An (Beirut: Muassasah al-Rayyan, 2001), 247-48. 


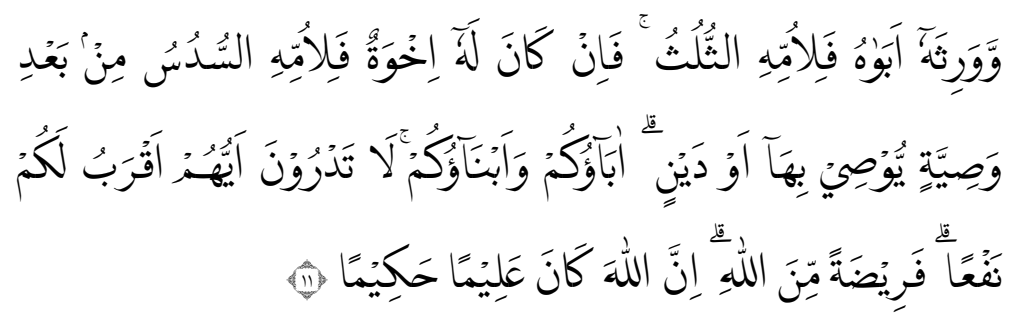

"Allah mensyariatkan (mewajibkan) kepadamu tentang (pembagian warisan untuk) anak-anakmu, (yaitu) bagian seorang anak laki-laki sama dengan bagian dua orang anak perempuan). Jika anak itu semuanya perempuan yang jumlahnya lebih dari dua, bagian mereka dua pertiga dari harta yang ditinggalkan. Jika dia (anak perempuan) itu seorang saja, dia memperoleh setengah (harta yang ditinggalkan). Untuk kedua orang tua, bagian masing-masing seperenam dari harta yang ditinggalkan, jika dia (yang meninggal) mempunyai anak. Jika dia (yang meninggal) tidak mempunyai anak dan dia diwarisi oleh kedua orang tuanya (saja), ibunya mendapat sepertiga. Jika dia (yang meninggal) mempunyai beberapa saudara, ibunya mendapat seperenam. (Warisan tersebut dibagi) setelah (dipenuhi) wasiat yang dibuatnya atau (dan dilunasi) utangnya. (Tentang) orang tuamu dan anak-anakmu, kamu tidak mengetahui siapa di antara mereka yang lebih banyak manfaatnya bagimu. Ini adalah ketetapan Allah. Sesungguhnya Allah adalah Maha Mengetahui lagi Mahabijaksana."58

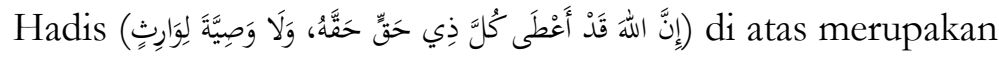
petunjuk/dalil adanya nasakh, dan hadis itu bukannya me-nasakh ayat tersebut. $^{59}$

Sedangkan golongan yang membolehkan me-nasakh ayat alQur'an dengan al-sunnah di antaranya yaitu madzhab Hanafiyyah, sebagian dari madzhab Malikiyyah, sebagian dari kalangan alSyafi iyyah seperti Imam al-Haramayn al-Juwayni dan al-Ghazali, dan Ibn Hazm al-Zhahiriy. Menurut golongan ini, al-sunnah

59 Al-Judai', Al-Muqaddimah Al-Asasiyyah Fi 'Ulum Al-Qur'An, 252. 
termasuk wahyu seperti halnya al-Qur'an, dan Allah sudah mewajibkan untuk taat kepada Nabi-Nya, dan dengan sepakat menyatakan bahwa penjelasan Nabi Saw. terhadap al-Qur'an merupakan bujjah seperti al-Qur'an. ${ }^{60}$

Masa berlangsungnya nasakh yaitu pada masa al-Risalah alNubunwah. Setelah masa itu tidak ada lagi, karena nasakh disandarkan pada wahyu yang matlu atau ghayru matlu. Wahyu matlu ialah al-Kitab (al-Qur'an), sedangkan wahyu ghaiyru matlu yaitu alsunnah (al-hadits). ${ }^{61}$

Syahrur sendiri memberikan bukti-bukti dari al-Quran, betapa wasiat ini sangat penting dan universal, jauh labih penting dari warisan. Dia bersandar pada QS. Al-Syura [42]: 13, yaitu: ${ }^{62}$

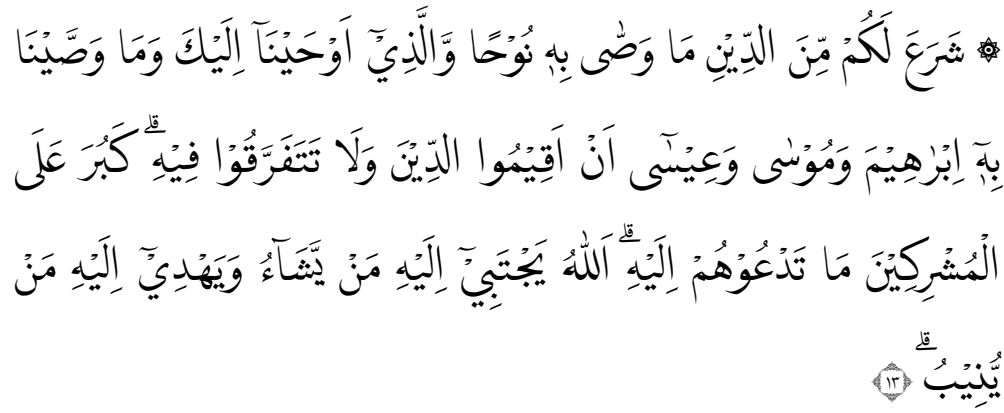

"Dia (Allah) telah mensyariatkan bagi kamu agama yang Dia wasiatkan (juga) kepada Nuh, yang telah Kami wahyukan kepadamu (Nabi Muhammad), dan yang telah Kami wasiatkan kepada Ibrahim, Musa, dan Isa yaitu: tegakkanlah agama (keimanan dan ketakwaan) dan janganlah kamu berpecah-belah di dalamnya. Sangat berat bagi orang-orang musyrik (untuk mengikuti) agama yang kamu serukan kepada mereka. Allah memilih orang yang Dia kehendaki pada

60 Al-Judai', 250-51.

${ }^{61}$ Khalid 'Abd al-Rahman Al-'Ak, Ushul Al-Tafsir Wa Qawa'Tdub (Beirut: Dar al-Nukhash, 1986), 302.

62 Najmil Husna, "Kritik Matan Hadis Muhammad Syahrūr," 132. 
(agama)-Nya dan memberi petunjuk pada (agama)-Nya bagi orang yang kembali (kepada-Nya)., ${ }^{, 63}$

Dari ayat ini, Syahrur mengeluarkan konsep sepuluh wasiat, yang berlaku hingga akhir zaman, yaitu: ${ }^{64}$

1. Tauhid, dengan sandaran QS. Al-Zumar [39]: 65.

2. Berbakti kepada orang tua, ini diwasiatkan kepada Nuh, Ibrahim, dan Musa.

3. Tidak membunuh anak-anak.

4. Tidak mendekati perbuatan keji. Larangan sodomi di masa Luth, zina di masa Musa dan lesbi di masa Muhammad.

5. Larangan membunuh, kepada Nabi Musa.

6. Tidak mencampuri harta anak yatim.

7. Memenuhi timbangan dan takaran.

8. Berbicara dengan adil, meskipun kepada sanak saudara.

9. Memenuhi janji Allah.

10. Mengikuti semua wasiat ini dengan sempurna, karena inilah shirath al-mustaqim.

Kesepuluh wasiat ini, berlaku terus-menerus sejak masa Nuh hingga akhir zaman. Persoalannya, bagaimana bisa ada hadis, yang melarang wasiat untuk disampaikan kepada ahli waris, padahal wasiat mesti ditunaikan, dari generasi ke generasi. Adapun warisan, ia adalah bagian dari wasiat, yang mesti ditunaikan. Bagi Syahrur, warisan yang ditunaikan setelah kematian, sangat tidak realistis, karena dia menundukkan sistem warisan kepada sistem wasiat.

Menurut Syahrur, pola pemahaman bahwa wasiat tidak bisa ditunaikan ke ahli waris, sesuai dengan hadis Nabi, telah terbentuk dari masa ke masa, hingga umat melupakan bahwa wasiat lebih penting dari warisan. Dalam kontekstualisasinya, Syahrur menetapkan bahwa ahli waris berhak mendapat wasiat karena ia

${ }^{63}$ QS. Al-Syura [42]: 13.

${ }^{64}$ Najmil Husna, "Kritik Matan Hadis Muhammad Syahrūr," 132-33.

140| TAJDID vol. 20, No. 1, Januari - Juni 2021 
berlaku terus menerus hingga akhir zaman. Adapun warisan hanya bagian kecil dari wasiat. ${ }^{65}$

\section{Penutup}

Hadis dalam pemahaman Syahrur merupakan produk sejarah dan dianggap bukan wahyu dari Allah Swt. Menurut Syahrur tidak ada istilah "al-wahyu al-tsani" terhadap hadis. Ia juga berasumsi bahwa para imam fikih melakukan pengultusan terhadap hadis supaya fatwa dari mazhabnya mempunyai legitimasi hukum dari hadis.

Hadis-hadis yang ditolak Syahur hampir semuanya dari jenis hadis yang sering dijadikan landasan para ulama dalam ber-istidlal. Ia menolak semua hadis yang dianggap sebagai naskh terhadap alQur'an. Karena menurutnya tidak ada naskh-mansukh dalam syariat. Kemudian ia mulai membongkar pemahaman naskh dalam hadis melalui analisis linguistik. Menurut Syahrur, hermeneutik sama dengan ta'wil, sedangkan pembacaan ulang terhadap hadis Nabi adalah hasil dari ta'wil. Tetapi, ta'wil yang dimaksud di sini adalah hermeneutik.

Pada pembahasan sebelumnya, penulis sudah memaparkan bahwa hadis atau sunnah termasuk wahyu ghaiyru matluw, bahkan Rasulullah pernah menegaskan bahwa perkataan beliau adalah sesuatu yang hak. Sedangkan dalam pembahasan naskh-mansukh, terdapat golongan yang membolehkan me-nasakh ayat al-Qur'an dengan al-sunnah yaitu madzhab Hanafiyyah, sebagian dari mazdhab Malikiyyah dan al-Syafi iyyah. Golongan ini juga memahami al-sunnah sebagai wahyu dan menyatakan bahwa penjelasan Nabi Saw. terhadap al-Qur'an juga termasuk bujjah sebagaimana al-Qur'an.

\section{Daftar Pustaka}

Al-'Ak, Khalid 'Abd al-Rahman. Ushul Al-Tafsir Wa QawaTduh. Beirut: Dar al-Nukhash, 1986.

\footnotetext{
${ }^{65}$ Najmil Husna, 132-33.
}

TAJDID vol. 20, No. 1, Januari - Juni 2021 | 141 
Al-Ghawri, Sayyid 'Abd al-Majid. Mawsu'ah Ulum Al-Hadits Wa Fununub. Vol. 3. Beirut: Dar Ibn Katsir, 2007.

Al-Judai', Abdullah bin Yusuf. Al-Muqaddimah Al-Asasiyyah Fi 'Ulum Al-Qur'An. Beirut: Muassasah al-Rayyan, 2001.

Al-Khathib, Muhammad 'Ajjaj. Ushul Al-Hadits: 'Ulumub Wa Mushthalabuh. Beirut: Dar al-Fikr, 1971.

Al-Nasa'i, Abi 'Abd al-Rahman Ahmad bin Syu'ayb bin 'Ali. Sunan Al-Nasa'i. Riyadh: Bayt al-Afkar al-Dawliyyah, n.d.

Al-Siba'i, Mushthafa. Al-Sunnah Wa Makanatuba Fi Al-Tasyri' AlIslami. Riyadh: Dar al-Waraq, n.d.

Al-Sijistani, Abu Dawud Sulayman ibn al-Asy'ats. Sunan Abu Dawnd. Riyadh: Bayt al-Afkar al-Dawliyyah, n.d.

Al-Syafici, Muhammad ibn Idris. Al-Risalah. Beirut: Dar al-Kutub al-'Ilmiyyah, n.d.

Anshori, Muhammad. "Sunnah Dan Kedudukan Muhammad Dalam Pandangan Muhammad Syaḥrūr." Jurnal Ilmiah Ilmu Ushuluddin 17, no. 2 (April 28, 2019): 99. https://doi.org/10.18592/jiu.v17i2.2239.

Ardiansyah, Ardiansyah. "KONSEP SUNNAH DALAM PERSPEKTIF MUHAMMAD SYAHRUR Suatu Pembacaan Baru Dalam Kritik Hadis." MIQOT: Jurnal Ilmu-Imu Keislaman 33, no. 1 (June 2, 2009). https://doi.org/10.30821/MIQOT.V33I1.160.

Aulassyahied, Qaem. "Studi Kritis Konsep Sunnah Muhammad Syahrur." KALIMAH 13, no. 1 (March 31, 2015): 139. https://doi.org/10.21111/klm.v13i1.282.

Fatah, Abdul. "KONSEP SUNNAH PERSPEKTIF MUHAMMAD SYAHRUR." Diroyah: Jurnal Studi Ilmu Hadis 4, no. 1 (September 30, 2019). https://doi.org/10.15575/DIROYAH.V4I1.6012.

Hakim, Nurul, and Tantin Puspita Rini. "Sunnah Perspektif Muhammad Syahrur." Al-Adabiya: Jurnal Kebudayaan Dan Keagamaan 15, no. 01 (June 5, 2020): 1-24. https://doi.org/10.37680/adabiya.v15i01.264. 
Idri. Studi Hadis. Jakarta: Kencana, 2010.

Najmil Husna, M. "Kritik Matan Hadis Muhammad Syahrūr." Jurnal Ilmu Pendidikan 3, no. 2 (2016): 113-35. https://journal.iainlangsa.ac.id/index.php/ikhtibar/article/ view/60.

Supena, Ilyas. Hermeneutika Al-Qur'an Dalam Pandangan Fąlur Rabman. Yogyakarta: Penerbit Ombak, 2014.

Surabaya, Pascasarjana IAIN Sunan Ampel. Hermeneutika Dan Fenomenologi Dari Teori Ke Praktik. Surabaya: Pascasarjana IAIN Sunan Ampel Surabaya, 2007.

Ulfiyati, Nur Shofa. "PEMIKIRAN MUHAMMAD SYAHRUR (Pembacaan Syahrur Terhadap Teks-Teks Keagamaan)." Et-Tijarie: Jurnal Hukum Dan Bisnis Syariah 5, no. 1 (December 4, 2018). https://journal.trunojoyo.ac.id/ettijarie/article/view/4597.

Wahid Syafi, M. "Sunnah Dalam Pandangan Muhammad Syahrur Dan Fungsinya Dalam Menafsirkan Al-Qur'an: Studi Analisis Tentang Poligami." Jurnal Manthiq 5, no. 2 (April 16, 2020). https://doi.org/10.29300/MTQ.V5I2.4388.

Yusuf, Muhammad. "BACAAN KONTEMPORER : Hermeneutika Al-Qur'an Muhammad Syahrur." Jurnal Diskursus Islam 2, no. 1 (April 22, 2014): 52-72. https://doi.org/10.24252/JDI.V2I1.6509.

Zahwu, Muhammad Abu. Al-Hadits Wa Al-Muhadditsun Aw 'Inayah Al-Ummah Al-Islamiyah Bi Al-Sunnah Al-Nabawiyah. Riyadh: al-Mamlakah al-'Arabiyah al-Su'udiyah, 1984. 